\title{
Studi Keragaman Struktur Morfologi dan Anatomi Petiole (Tangkai Daun) Dari Berbagai Kultivar Pisang Kepok (Musa Paradisiaca L.)
}

\section{Study Structures Morphology and Anatomy Petiole (Tangkai Daun) From Various Cultivar Of Pisang Kepok (Musa Paradisiaca L.)}

\section{Galuh Putri Anjasmara ${ }^{1^{*}}$, Eti Ernawiati ${ }^{2}$, Gina Dania Pratami ${ }^{2}$, dan Endah Setyaningrum ${ }^{2}$}

${ }^{1,2}$ Jurusan Biologi / FMIPA Universitas Lampung

*E-mail: galuhputrianjasmara0@gmail.com

\begin{abstract}
Kepok bananas are one type of banana that is found and used in Indonesia. These bananas contain high nutritional value so they are suitable for use as food ingredients. This study aims to determine the anatomical structure and morphology of petiole from various banana kepok cultivars. These cultivars are: kepok abu, batu, kapas, kuning, Libanon, and Manado. However, Kepok Libanon cannot be found in the previous collection area. The research was conducted in December 2018 to January 2019. The taking of plant samples using the method of exploration and observation of anatomical structures using fresh preparations across the incision and the results were analyzed descriptively. The observation of the structure of morphology of petiole is the largest petiole diameter, namely kepok kapas while the smallest is kepok batu. Kepok batu is the only one that has a canal leaf shape overlaps while kepok abu, kapas, kuning, and manado have the leaf shape of a curved canal inside. The fifth color of the kepok banana cultivar is the same which is green. Kepok abu have blackish brown spots while kepok batu, kapas, kuning, and manado have brown spots. The anatomical structure of the petiole includes the xylem diameter, transport tissue, support tissue, basic tissue, and protector tissue. Kepok kapas has the largest xylem diameter while kepok kuning has the smallest xylem diameter. Five kepok banana cultivars, has xylem and phloem transport tissue were clearly seen by the sclerenchyma sheath. Epidermal, parenchymal, and sclerenchymal tissue were clearly seen in the five cultivars.
\end{abstract}

Keywords : Cultivar, Kepok banana, Petiole, and Xylem

Disubmit: 8 Desember 2019; Diterima : 28 Desember 2019; Disetujui : 16 Januari 2020

\section{PENDAHULUAN}

Indonesia adalah salah satu negara penghasil tanaman holtikultura dari kelompok tanaman buahbuahan. Salah satu jenis tanaman yang banyak dijumpai adalah tanaman pisang. Iklim tropis yang sesuai serta kondisi tanah yang banyak mengandung humus membuat tanaman pisang sangat cocok dan tersebar luas di Indonesia. Di Asia Tenggara sendiri tanaman pisang pertama kali ditemukan di dataran rendah di area timur Indonesia sekitar 5000 tahun sebelum masehi (Dwiyany, F. dan Nurrahmah, 2017). Pada zaman dahulu ditemukan dua jenis pisang yang dapat dimakan yaitu berasal dari hasil persilangan spesies Musa acuminata (genom AA) dan Musa balbisiana (genom BB) didalam seksi eumusa (Purseglove, 1975). Dari 
kedua jenis pisang di atas, terdapat berbagai variasi genetik melalui proses yang berperan penting dalam evolusi tanaman pisang (Wahyuningtyas, W. Retno, A. dan Rahayu, 2009)

Evolusi pisang liar menghasilkan kultivar pisang dengan berbagai tingkat ploidi dengan variasi genom AA, BB, AB, AAA, AAB, ABB, AAAA, ABBB, AAAB, dan AABB (Stover dan Simmonds, 1987). Diperkirakan terdapat sekitar 1000 kultivar pisang yang tersebar di dunia. Di Indonesia pada saat ini telah berhasil diidentifikasi kurang dari 200 kultivar pisang (Nuryanti, 2014). Salah satunya yaitu kultivar-kultivar pada pisang kepok. Di Kota Bandar Lampung, terdapat 6 kultivar pisang kepok yaitu abu, batu, kuning, kapas, libanon, dan manado (Nurhasanah, 2017).

Secara morfologi, tanaman pisang memiliki bagian-bagian utama yaitu: akar, batang, daun, bunga, dan buah. Daun pisang termasuk daun lengkap meliputi Upih (pelepah daun), petiole (tangkai daun), dan lamina (helai daun) (Nugroho, H. Purnomo. dan Sumardi, 2006). Petiole tanaman pisang memiliki beberapa struktur morfologi yang khas yaitu seperti bentuk tangkai daun dan laminanya (Ennos, A.R. Spatz, Speck, 2000). Struktur anatomi pada petiole tangkai pisang lebih berkarakteristik dimana petiole memiliki jaringan pengangkut dan ikatan pembuluh yang kompleks dan jelas.

Struktur morfologi yang khas dan struktur anatomi yang berkarakteristik pada petiole pisang kepok ini, menyebabkan perlu dilakukannya studi keragaman morfologi dan anatomi petiole untuk melihat apakah pada kultivar pisang kepok yang telah diidentifikasi (Nurhasanah, 2017), memiliki perbedaan baik pada struktur morfologi maupun struktur anatominya.

\section{METODE PENELITIAN}

Penelitian dilaksanakan mulai bulan Desember sampai Januari 2019. Tangkai daun (petiole) berbagai kultivar pisang kepok dikumpulkan menggunakan metode eksplorasi dari pekarangan warga Kota Bandar Lampung dan Kabupaten Pesawaran, Provinsi Lampung. Pembuatan preparat segar sayatan melintang tangkai daun dilakukan di Laboratorium FMIPA Unila.

Petiole pisang kepok masing-masing kultivar diambil 3 posisi petiole dari 1 pohon yang sama dan dilakukan pengulangan pada 3 pohon yang berbeda. Posisi petiole yang diambil adalah atas, tengah, dan bawah. Dengan demikian, dari 1 kultivar terdapat 9 petiole yang berbeda yang akan digunakan dalam penelitian.

Karakterisasi struktur morfologi petiole menggunakan panduan deskriptif dari (IPGRI, 1996). Karakter yang diamati adalah diameter petiole, bentuk daun kanal, warna petiole, dan bercak pada petiole. Pembuatan preparat segar sayatan melintang dilakukan berdasarkan penelitian (Sa'adah, 2015), petiole diiris tipis secara melintang, diletakan di atas gelas objek kemudian ditetesi aquades dan diamati menggunakan mikroskop perbesaran 10x dengan parameter yang diamati yaitu diameter xylem, tipe ikatan pembuluh, dan jaringan pengangkutnya.

\section{HASIL DAN PEMBAHASAN}

Diameter petiole. Hasil pengukuran diameter petiole 5 kultivar pisang kepok pada 3 posisi berbeda menunjukan variasi, meskipun tidak terlampau besar, pisang kepok kapas memiliki ukuran rata-rata diameter petiole terbesar dan terkecil terdapat pada kultivar kepok batu (Tabel 1). Hal ini dapat terjadi diduga karena pengambilan sampel petiole pada saat eksplorasi tidak pada penomoran petiole yang sama, kemudian hal lain yang dapat terjadi adalah karena jika dilihat secara kasat mata ukuran tanaman dari kepok kapas lebih besar dari kultivar kepok lainnya sehingga berpengaruh terhadap ukuran petiole. 
Anjasmara dkk : Studi Keragaan Struktur Morfologi dan Anatomi Petiole (Tangkai Daun)......

Tabel 1. Ukuran diameter petiole dari berbagai kultivar pisang kepok

\begin{tabular}{lccc}
\hline Jenis Pisang & \multicolumn{3}{c}{ Diameter Petiole $(\mathrm{cm})$} \\
\cline { 2 - 4 } & Pangkal & Tengah & ujung \\
\hline Kepok Abu & 3,37 & 3,02 & 2,83 \\
Kepok Batu & 2,90 & 2,63 & 2,44 \\
Kepok Kapas & 4,06 & 3,71 & 3,39 \\
Kepok Kuning & 3,21 & 3,16 & 2,8 \\
Kepok Manado & 3,72 & 3,21 & 2,96 \\
\hline
\end{tabular}

Struktur Morfologi. Petiole kelima kultivar pisang kepok ini memiliki struktur morfologi yang hampir sama dimana 4 kultivar yaitu abu, kapas, kuning, dan manado memiliki bentuk daun kanal melengkung kedalam. sedangkan kultivar kepok batu memiliki bentuk daun kanal tumpang tindih. Warna petiole pada seluruh kultivar pisang kepok sama yaitu berwarna hijau dengan sedikit bercak coklat pada kultivar batu, kapas, kuning, dan manado serta bercak coklat kehitaman mencolok pada kultivar abu (Tabel 2).

Petiole kelima kultivar pisang kepok ini memiliki struktur morfologi yang hampir sama dimana 4 kultivar yaitu abu, kapas, kuning, dan manado memiliki bentuk daun kanal melengkung kedalam. sedangkan kultivar kepok batu memiliki bentuk daun kanal tumpang tindih. Warna petiole pada seluruh kultivar pisang kepok sama yaitu berwarna hijau dengan sedikit bercak coklat pada kultivar batu, kapas, kuning, dan manado serta bercak coklat kehitaman mencolok pada kultivar abu (Tabel 2).

Kepok kapas, kuning, dan manado adalah bergenom BBB (Musa balbisiana), hal ini senada dengan pendapat (Sulistyaningsih LD, Megia R, 2014), yang mengatakan bahwa pisang kepok bergenom BBB (Musa balbisiana) seperti kepok kapas, kuning, dan manado memiliki bentuk daun kanal melengkung kedalam seperti tetua M. balbisiana yang ada di Pulau Sulawesi. Sedangkan bentuk daun kanal kepok batu mirip dengan tetua M. balbisiana yang da di Pulau Jawa yaitu tumpang tindih (Hapsari L, 2014).

Warna bercak pada petiole pisang kepok diduga mengikuti genomnya BBB. Pisang kepok kapas, kuning, dan manado bergenom BBB (Musa balbisana) memiliki warna bercak coklat dan tidak mencolok. Hal ini senada dengan pendapat (Rahmawati, M. \& Hayati, 2013), yang mengatakan bahwa petiole yang berwarna tidak mencolok memiliki sifat M. balbisiana, sedangkan warna bercak mencolok dan coklat kehitaman pada kepok abu (bergenom AAB) diduga karena kepok kultivar ini merupakan persilangan dari M. acuminata dan M. balbisiana dengan karakter yang dominan kepada M. acuminata dengan salah satu karakter yang dimiliki adalah bercak yang coklat kehitaman, pekat, dan mencolok (Rahmawati, M. \& Hayati, 2013).

Tabel 2. Struktur morfologi petiole dari berbagai kultivar pisang kepok

\begin{tabular}{lccc}
\hline \multirow{2}{*}{ Jenis Pisang } & \multicolumn{3}{c}{ Karakter } \\
\cline { 2 - 4 } & $\begin{array}{c}\text { Bentuk daun Kanal } \\
\text { Petiole }\end{array}$ & Warna Petiole & Warna Bercak \\
\hline Kepok Abu & $\begin{array}{c}\text { Melengkung } \\
\text { Kedalam }\end{array}$ & Hijau & Coklat kehitaman \\
Kepok Batu & $\begin{array}{c}\text { Tumpang Tindih } \\
\text { Kepok Kapas }\end{array}$ & Hijau & Coklat \\
Kengkung & Hijau & Coklat \\
Kedalam & Melengkung & Hijau & Coklat \\
Kepok Kuning & $\begin{array}{c}\text { Kedalam } \\
\text { Kengkung }\end{array}$ & Hijau & Coklat \\
\hline
\end{tabular}


Diameter Xilem. Kultivar pisang kepok dengan rata-rata diameter xylem terbesar ada pada kultivar pisang kepok kapas sedangkan yang terkecil adalah kultivar kepok kuning (Tabel 3). Sama halnya dengan diameter morfologi petiole, besar kecilnya diameter dari xylem ini diduga karena pengambilan sampel dilapangan dilakukan secara acak.

Tabel 3. Ukuran diameter xylem petiole dari berbagai kultivar pisang kepok

\begin{tabular}{lccc}
\hline \multirow{2}{*}{ Jenis Pisang } & \multicolumn{3}{c}{ Diameter Xilem $(\mu \mathrm{m})$} \\
\cline { 2 - 4 } & Pangkal & Tengah & Ujung \\
\hline Kepok Abu & 21,6 & 22,1 & 20,8 \\
Kepok Batu & 21,4 & 24,2 & 21,8 \\
Kepok Kapas & 23,8 & 24,4 & 22,7 \\
Kepok Kuning & 19,1 & 19 & 19,3 \\
Kepok Manado & 18,9 & 19,1 & 22,5 \\
\hline
\end{tabular}

Petiole M. balbisiana dan M. paradisiaca disusun oleh tiga jaringan yaitu : epidermis, parenkim, dan berkas pengangkut (Sunandar, A. dan Kahar, 2018). Struktur anatomi petiole pisang kepok dari kelima kultivar yang diamati pun sama yaitu lapisan epidermis pada bagian paling luar, kemudian terdapat jaringan parenkim yang tersebar hampir diseluruh bagian. Pada bagian tengah terdapat jaringan parenkim yang menyimpan udara yang disebut aerenkim. Ditemukan pula jaringan pengangkut dan ikatan pembuluh berupa xylem dan floem yang dikelilingi oleh selubung sklerenkim serta sklerenkim yang dapat dilihat dibawah epidermis.

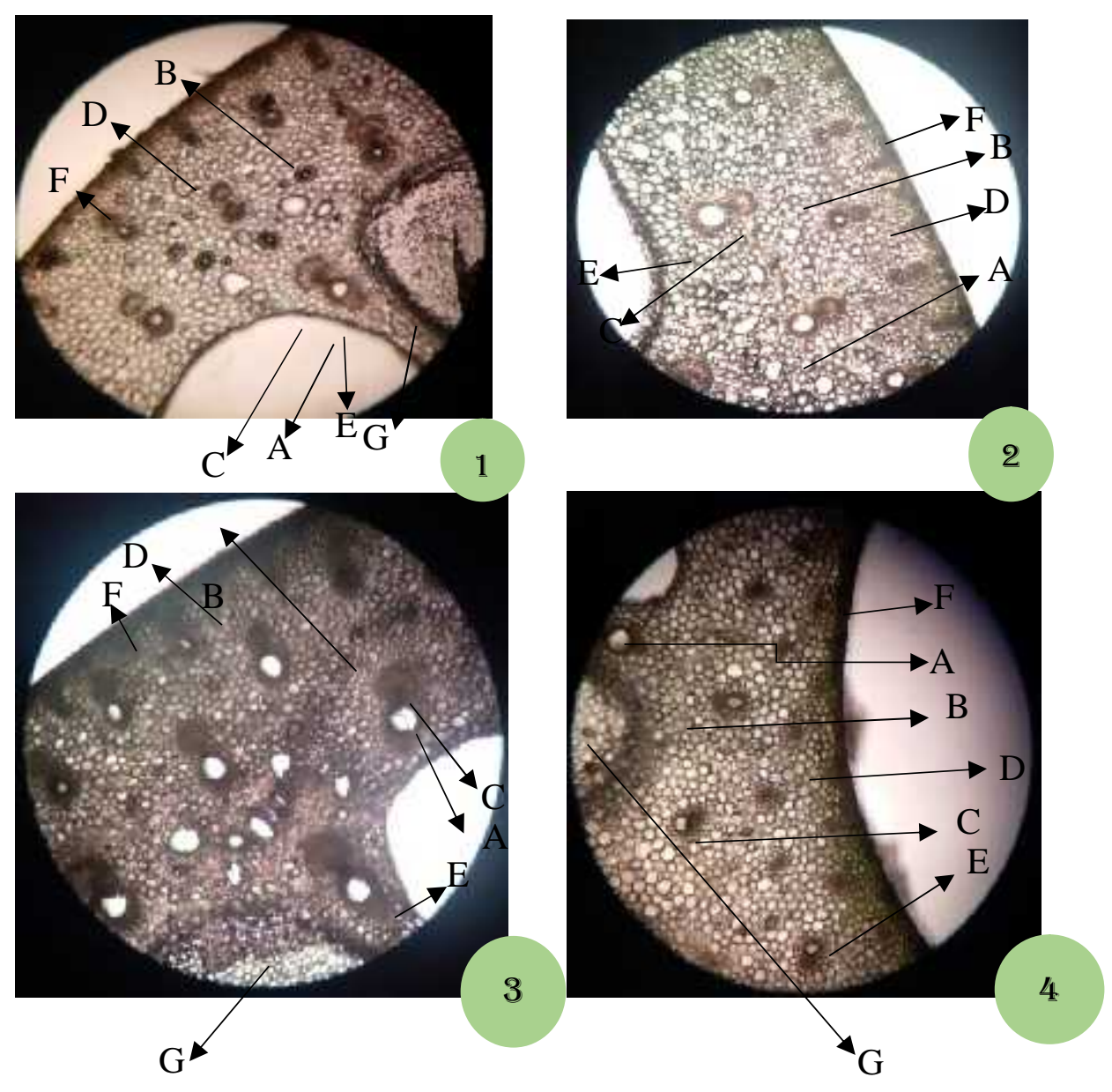




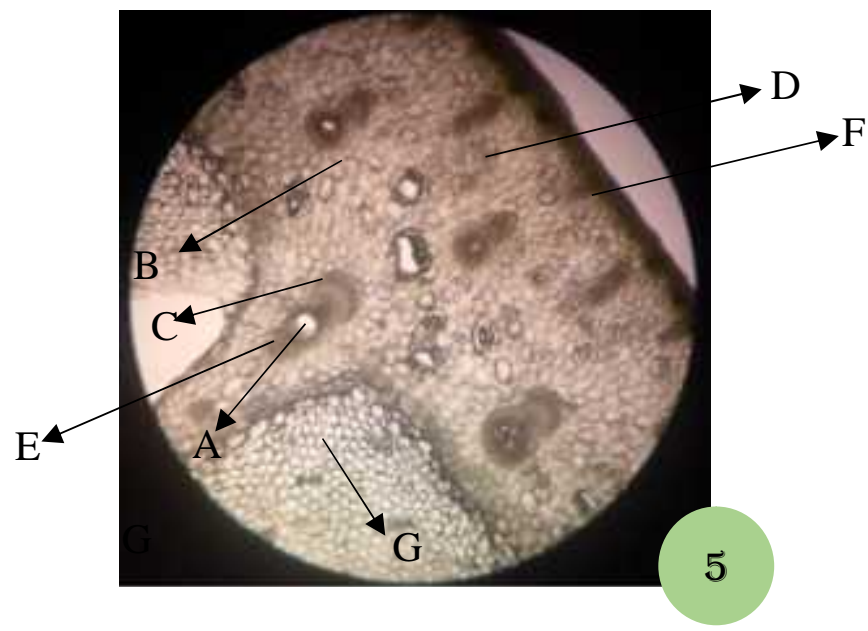

Gambar 1. Struktur anatomi petiole dari berbagai kultivar pisang kapok. [1] kapok abu, [2] kapok batu, [3] kapok kapas, [4] kapok kuning, [5] kapok manado.

Keterangan : A: Xylem; B: sel parenkim; C: floem; D: sklerenkim; E: sklerenkim sheath; F: epidermis; G: aerenkim

\section{KESIMPULAN}

Pisang kepok kultivar kapas memiliki diameter petiole dan diameter xylem terbesar, sedangkan kepok batu memiliki diameter petiole terkecil dan kepok kuning memiliki diameter xylem terkecil. seluruh petiole kultivar pisang kepok memiliki warna hijau dengan daun kanal yang tumpang tindih pada kepok batu dan melengkung kedalam pada kepok abu, kapas, kuning, dan manado. Warna bercak pada petiole kepok abu adalah coklat kehitaman sedangkan pada kepok batu, kapas, kuning, dan manado adalah coklat.

\section{DAFTAR PUSTAKA}

Dwiyany, F. dan Nurrahmah, A. (2017) Pentingnya Data Pisang Indonesia. Bunga Ramp. Bandung: ITB.

Ennos, A.R. Spatz, Speck, T. (2000) 'The functional morphology of the petioles of the banana, Musa textilis', Journal of Experimental Botany, (51), p. 353.

Hapsari L (2014) 'Wild Musa species collection of Purwodadi Botanic Garden: Inventory and its morphotaxonomic review', Journal of Tropical Life Science, 4(1), pp. 70-80.

IPGRI (1996) Descriptors for Banana (Musa spp.). International Plant Genetic Resources Institute: INIBAP.

Nugroho, H. Purnomo. dan Sumardi, I. (2006) Struktur dan Perkembangan Tumbuhan. Jakarta: Swadaya.

Nurhasanah, E. (2017) Biodiversitas Plasma Nutfah (Musa spp) Berdasarkan Jumlah Kromosom dan Tipe Genom di Kota Bandar Lampung. Universitas Lampung.

Nuryanti, L. dan N. (2014) Outlook Komoditi Pisang. Pusat Data dan Informasi Pertanian, Sekertariat Jenderal Kementrian Pertanian.

Purseglove, J. W. (1975) Tropical Crops: Monocotyledons. 2nd impression. Banana. 3r. Edited by Stover; R. H and N.W. Simmonds. Halsted Press, New York: Logman: London.

Rahmawati, M. \& Hayati, E. (2013) 'Pengelompokan Berdasarkan Karakter Morfologi Vegetatif pada Plasma Nutfah Pisang Asal Kabupaten Aceh Besar', Jurnal Agrista, 17(3), pp. 111-118. 
Jurnal Penelitian Pertanian Terapan

Sa'adah, L. (2015) Karakterisasi Morfologi Dan Anatomi Selada Air (Nasturtium spp.) Di Kabupaten Batang Dan Semarang Sebagai Sumber Belajar Dalam Mata Kuliah Morfologi Dan Anatomi Tumbuhan. UIN Walisongo. Semarang.

Sulistyaningsih LD, Megia R, W. E. (2014) 'Two New Record of Wild Bananas (Musa balbisiana and Musa intinerans) from Sulawesi. Makara', J Sci., 18(1), pp. 1-6.

Sunandar, A. dan Kahar, P. (2018) 'Karakter Morfologi dan Anatomi Pisang Diploid dan Triploid', Scripta Biologica, (5), pp. 31-36.

Wahyuningtyas, W. Retno, A. dan Rahayu, S. E. (2009) 'Keanekaragaman Genetika Pisang Bergenom B Berdasarkan Penanda Mikrosatelit', Biosaintifika, 1(1), pp. 1-10. 